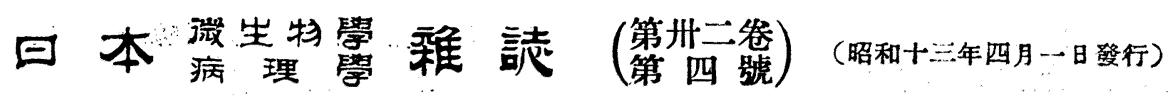

（原著）

\title{
人血清二於ヶルちろす Vi凝集素ノ研究
}

\author{
第 2 編 腸ちふす患者並二恢復者血清二 \\ 關スル實驗
}

京都帝國大學㗨學部微生物學教室 (主任 木村敎授)

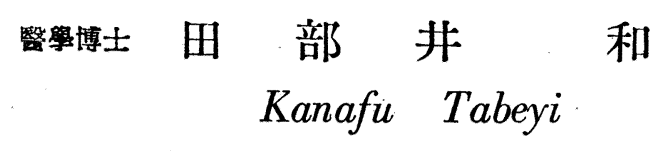

醫學士 梅 敷軍次

\section{Gunji Baishiki}

醫學士片 岡 貞義

Sadayoshi Kataoka

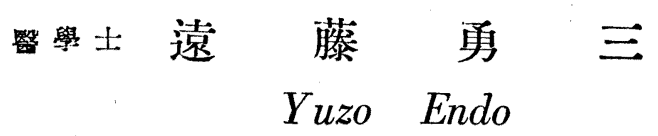

（昭和 13 年 2 月 28 日受付）

\section{【内容 抄 淥】}

余等八, 暴二本研究)第 1 編トシテ正常人.血清二關スル實驗 $=$ 就イテ報告 (日微生物誌第 32 炝 3號302頁昭和13年) シタ：今回八晹ちふす患者前二同恢復者血清及ビ既往二於テ腸ちふすョ經驗

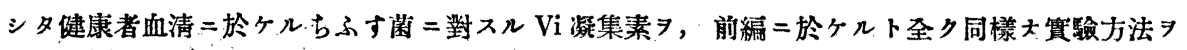
以テ检查シタカラ，其ノ成縤二就テ報告スル。

目次

緒 言

第 1 章 實驗材料及ビ贯驗方法

第 1 節 贯驗材料

第 2 管 實验方法

\section{第 2 章 寞驗成綪}

第 1 節 登病第 1 週 $=$ 於ヶル血清 $=$ 關スル 成績

第 2 節 登病第 2 週=於ケ几血清二關スル 


\author{
成鈢 \\ 第 3 節 登病第 3 週=於ケル血清=關スル \\ 成績 \\ 第 4 節 登病第 4 遇乃至26週二於ケル血清 \\ 二關ス几成績
}

\section{第 5 節 既往=於テちふすす經驗七几健康} 者血清二關ス几成績

第 3 章 總括考按出 $=$ 結諭

文解

\section{精 宮}

余等八軖二，本研究）第 1 回郝告(1)トシテ, 健康者（ちふす豫防接種者

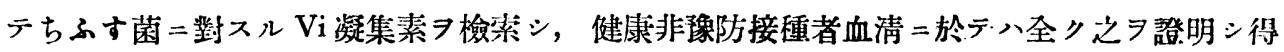

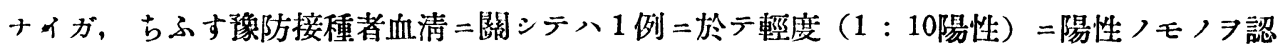
メタコトラ報告シタ.

今回八腸ちふす患者並二恢復者及ビ既往ニ於テ腸ちふすフ經驗シタ者ノ血清二關シテVi凝 集素含有ノ有無》檢查シタノデアルガ, コノ問題 =關シテハ, 既 = Felix, A., Krikorian., $K . S$. 及ビ Seitler., R.(2)八ちふす患者血清二於テハ多クノ場合 Vi 凝集素习登明スルコト 八出來ナイガ，ちふすす恢復期患者血清＝於テハ甚ダ屢《之證朋シ得ルコトヨ報告シ， $M$. Gundel 及ビ $Y . B . A b d o o s h(3)$ 八腸ちふす患者血清41例中其 45 例 =於テ Vi 凝集琵 7 證明 スルコトガ出來タガ, 恢復期患者血清 =於テハ11例中只 1 例 =於テノミ之レヨ證明スルコト ガ出來夕卜報告シ, 叉 Horgen, E. S.(4) 八腸ちふす患者血清52例中12例=於テノミ Vi凝集 素习登明シ得タコトカラ $\mathrm{Vi}$ 凝集反應へちふすノ診斷＝向ツテ大ナル意義ヨ有スルモノデハ ナイト述ベテ居ルノデアル。

卜述諸家ノ業績 7 通覧スルト, Felix, A., Krikorian, K. S. 及ビ Seitler, R.(2) 及ど Horgen, E. S. (4) ，所說八太體=於テー政シテ居ルガ，M. Gundel 及ビ Y.B.Abdoosh (3) 八所說八前二者ノ其レト八稍々異ルャウデフル. 然シ作ラ, Vi 凝集素ガちふす患者及ビ同恢 復者血清こ於テ, 每常例外ナシニ, 證明サレ得ルモノデナイコトニ關シテハ, 上述諸家，意 見ハ凡ソー致シテ居ルノデアル.

余等八, 昭和 11 年 8 月以降京阪地方デちふす患者血埨, 同恢復者血清及ビ既往二於テちふ すヨ經驗七ルモ，血清合計72例 集素ヨ檢索シテ聊カ知見ヨ得タカラ, 其等二就テ簡單 =報告シ各位つ御批制 モノデル。

\section{第 1 童 實驗材料及ビ賽驗方法 \\ 第 । 節 供試血清/菟集}

余等力本惯驗，雼メ二鬼集シタ血站、 


\begin{tabular}{|c|c|c|c|}
\hline & \multirow{2}{*}{$\begin{array}{c}5 \text { 例 } \\
13 \text { " }\end{array}$} \\
\hline \multicolumn{3}{|c|}{ 發病後 1 週間以內，モ， } & \\
\hline "I & 3 & "I & $13 / /$ \\
\hline II & 4 & "I & $5 /$ \\
\hline "I & 5 & "I & $10 / /$ \\
\hline II & 6 & II & $5 / 1$ \\
\hline "I & 7 & 11 & $3 / 1$ \\
\hline "I & 8 & "I & $5 / 1$ \\
\hline
\end{tabular}

發病後 9 週以內ノモノ 2 例

" $11-26$ " 4 "I

既往 =於テ腸ちふす 經驗七ル者ノ血清 8 例

總計72例デ，京大醫學部附屬䣽院隔離病舍（京大）ヨリ24例，大阪市立桃山病院（䄻川） ヨリ17例, 宗都病院 (京都) ヨリ17例, 敎室關係者ヨリ 7 例 ヨ蒐集シタモノデアル。

之等血液カラ八血清 7 分離シ, 防腐 $/$ 目的 $=0.1 \%=$ Formalin 7 加へ, 直チ=實驗=供ス ルコトトシタ.

\section{第 2 第實驗方法}

前回ノ報告ト古ク闹栐デアルカラ茲二八省略スル。

供試血清二就テハ每:常 Vi 凝集文隹卜通常凝集反應 併七テ施行スルコトトシ，本實驗二使 用シタ菌株证二實驗方法ハ總テ前回ノ其レト同羕デアルガ, 純粹ナ Vi 血清 使用シタ菌量八，當該血清ノ通常凝集價二應ジテ，每常其ノ充分量ラ用フル事トシタ.

\section{第 2 童筫 驗成 績}

腸ちふすノ診斷二於テ, 患者血清っラちふす菌ラ直接培食證明スルコトハ素ヨリ重要ナル 診斷法ノ・-ツデアルガ，患者血清ニ就テ行フ Widalsche Reaktion モ亦重要ナ方法デアルコ トハ今更述・ル迄モナイコトデアル.本實驗二於テハ，ちふすノ各病期二於ケル通常凝集反

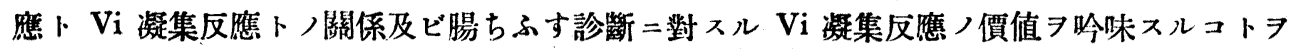
以テ主ナル研究目的トシテ居ルカラ, 72例ノ供試血清二就テハ之レラ發病ヨリノ經過日數， 順序二列記シ，而シテ發病後第 1 週以內 ノモノ，發病後第 2 週以內ノモノ等ノ如ク一括シテ

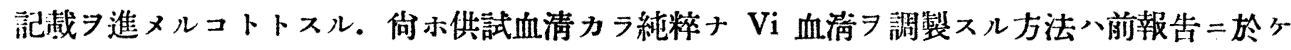
ルト同樣二, W型63號菌生菌ヨ以テ吸收調製シタ場合及ビ監酸處置菌 合トガアルガ之等八表中二明記スルコトトスル. 


\section{第 I節 發病第 1 週二於ヶル゙血清二關スル成績}

本實驗 $=$ 於テハ 5 例ノ血清习檢查シタ.之等ノ內ノ 1 例八發病後第 6 日目二採取シタモ， デアリ，他ハ總テ發病第 7 日目二探取シタモノデアル。實驗成績八第 1 表二示ス如クデアル。

第 1 表

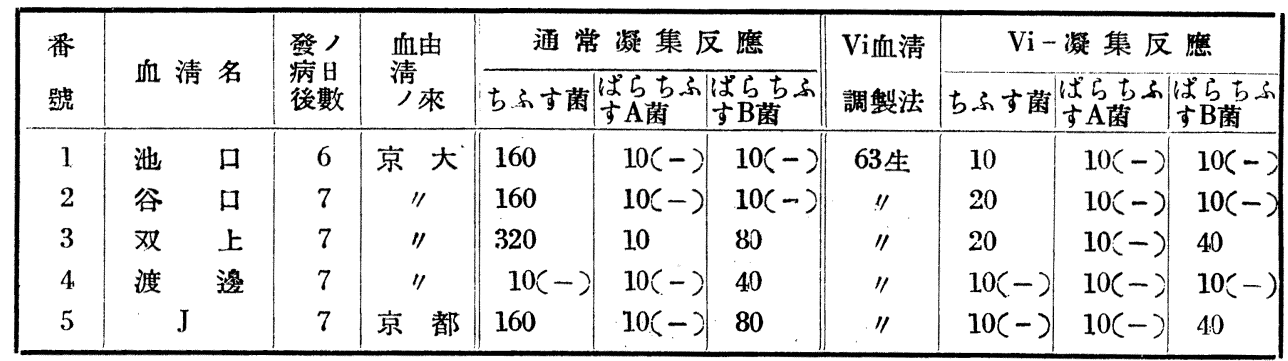

第 1 表 $=$ 示ス如ク, 渡邊血清 7 除ク他八總テ各喠凝集元 $=$ 對スル通常凝集反雇，凝集價》

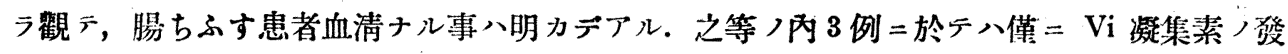

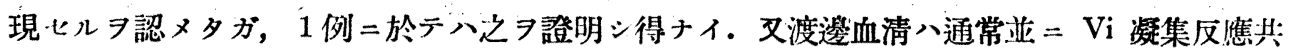
二陰性デ，本實驗ノ成績ノミヨ以テスレバ, 腸ちふすノ揨斷习附スル事八出來ナイノデアル ガ, 此ノ血清八, 次笁二於テ述ベル如ク, 發病第 2 週 檢查デ明カ二腸ちふすナル事ガ證 明出來タモノデアル。

要スル $=$, 發病第 1 週ノ血清 $=$ 於テハ, 通常凝集反應 集素つ發見习證明シ得ナイ例ガ存在スルモノデテル。

第 2 節。發病第 2 週二於ケル血清二關スル成績

本節 $=$ 於テ八發病後第 8-14日迄二採取シタ血清13例 7 檢查シ夕. 成樍八笨 2 表二示ス如 クデアル.

第 2 表

\begin{tabular}{|c|c|c|c|c|c|c|c|c|c|c|c|}
\hline \multirow{2}{*}{$\begin{array}{l}\text { 番 } \\
\text { 號 }\end{array}$} & \multirow{2}{*}{\multicolumn{2}{|c|}{ 血 清 名 }} & \multirow{2}{*}{$\begin{array}{l}\text { 發当 } \\
\text { 後數 }\end{array}$} & \multirow{2}{*}{$\begin{array}{l}\text { 血由 } \\
\text { 清 } \\
\text { /來 }\end{array}$} & \multicolumn{3}{|c|}{ 通 常 凝 集 反 應 } & \multirow{2}{*}{$\begin{array}{l}\text { Vi血清 } \\
\text { 調製法 }\end{array}$} & \multicolumn{3}{|c|}{ Vi - 㠜 集 反應 } \\
\hline & & & & & 万ふす菌 & 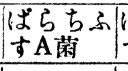 & $\begin{array}{l}\text { は⿱ららちな } \\
\text { すB菌 }\end{array}$ & & 万小す菌 & 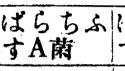 & 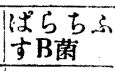 \\
\hline 6 & 本 & 野 & 9 & 京 大 & 160 & $10(-)$ & 10 & 63生 & $10(-)$ & $10(-)$ & 10 \\
\hline 7 & 島 & 田 & 9 & 京 都 & 640 & $10(-)$ & 40 & $"$ & 10 & $10(-)$ & $10 c-$ \\
\hline 8 & 场 & 野 & 10 & 京 大 & 1280 & $10(-)$ & 20 & "I & 40 & $10(-)$ & $10(-)$ \\
\hline 9 & $\mu i$ & 村 & 10 & "I & 320 & $10(-)$ & 40 & 盬酸 & $10(-)$ & $10(-)$ & 20 \\
\hline 10 & A & & 10 & " & 160 & $10(-)$ & $10(-)$ & 63生 & $10(-)$ & $10(-)$ & $10(-)$ \\
\hline 11 & 佐 \& & 田 & 11 & " & 640 & $10(-)$ & $10(-)$ & "I & 10 & $10(-)$ & $10<->$ \\
\hline 12 & 川 才 & 村 & 12 & " & 1280 & $10(-)$ & 10 & 11 & 10 & $10(-)$ & $10(-)$ \\
\hline
\end{tabular}




\begin{tabular}{|c|c|c|c|c|c|c|c|c|c|c|}
\hline \multirow{2}{*}{$\begin{array}{l}\text { 番 } \\
\text { 胧 }\end{array}$} & \multirow{2}{*}{ 血 清 名 } & \multirow{2}{*}{$\begin{array}{l}\text { 發, } \\
\text { 病昆 } \\
\text { 數 }\end{array}$} & \multirow{2}{*}{$\begin{array}{l}\text { 血由 } \\
\text { 清 } \\
\text { 八來 }\end{array}$} & \multicolumn{3}{|c|}{ 通 常 凝 集 反 應 } & \multirow{2}{*}{$\begin{array}{l}\text { Vi血!清 } \\
\text { 調整法 }\end{array}$} & \multicolumn{3}{|c|}{ Vi－㠜 集 反應 } \\
\hline & & & & 与ふす菌 & $\begin{array}{l}\text { ぱらちふ } \\
\text { すA菌 }\end{array}$ & $\begin{array}{l}\text { ぱらちら } \\
\text { すB菌 }\end{array}$ & & ちふす菌 & 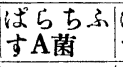 & $\mid \begin{array}{l}\text { らちら } \\
\text { すB菌 }\end{array}$ \\
\hline 13 & 上 & 12 & 京 大 & 320 & $10(-)$ & $10(-)$ & 鑒酸 & 40 & $10(-)$ & $10(-)$ \\
\hline 14 & 諸 & 12 & "I & 2560 & $10(-)$ & 80 & 63生 & 80 & $10(-)$ & 20 \\
\hline 15 & 丸 & 12 & 京 都 & 160 & $10(-)$ & 40 & 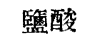 & 10 & $10(-)$ & $10(-)$ \\
\hline 16 & 山 & 14 & 京 大 & 640 & $10(-)$ & 80 & "1 & 40 & $10(-)$ & 40 \\
\hline 17 & 渡 & 14 & "1 & 640 & $10(-)$ & 160 & 63生 & $10(-)$ & $10(-)$ & $10(-)$ \\
\hline 18 & 木 & 1.4 & 京 都 & 1280 & 80 & 320 & "I & 80 & $10(-)$ & 40 \\
\hline
\end{tabular}

第 2 表通常凝集反應ノ成績カラ, 之等ノ13例ガ總テ腸ちふす患者血清デアルコトハ明白デ

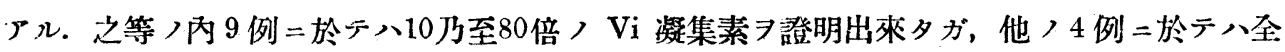

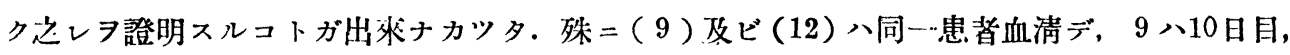
12 ハ 12 日目二夫々探取シタモノデアルガ, 前者二於テハ Vi 凝集素习證明シ得ナイデ後者二

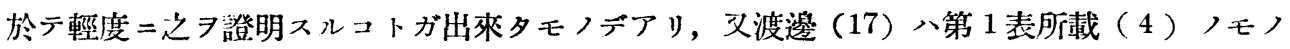
卜同一患者ノ血清デアツタガ，此血清二於テハちふす菌＝對スル通常㠜集價ハ640倍ヨ示シ 夕ノ= Vi 凝集菜ハ之レヨ全ク證明シ得ナカツタモノデアル.

\section{第 3 第 發病第 3 週二於ケル血清二關スル成樍}

發病第15万至21日後二採取シタ血清13例

第 3 表

\begin{tabular}{|c|c|c|c|c|c|c|c|c|c|c|c|}
\hline \multirow{2}{*}{$\begin{array}{l}\text { 番 } \\
\text { 號 }\end{array}$} & \multirow{2}{*}{\multicolumn{2}{|c|}{ 血. 清 名 }} & \multirow{2}{*}{$\begin{array}{l}\text { 發尚 } \\
\text { 病昆 } \\
\text { 數 }\end{array}$} & \multirow{2}{*}{$\begin{array}{l}\text { 血由 } \\
\text { 清 } \\
\text { 八來 }\end{array}$} & \multicolumn{3}{|c|}{ 通常 凝 集 反 虑 } & \multirow{2}{*}{$\begin{array}{l}\mathrm{Vi} \text {-血淈 } \\
\text { 調製法 }\end{array}$} & \multicolumn{3}{|c|}{$\mathrm{Vi}$-凝集 反應 } \\
\hline & & & & & ちふす菌 & $\begin{array}{l}\text { ばらちふ/ } \\
\text { すA菌 }\end{array}$ & $\begin{array}{l}\text { ばらちふ } \\
\text { すB菌 }\end{array}$ & & ちふす寸菌 & $\begin{array}{l}\text { ばらちふ } \\
\text { すA菌 }\end{array}$ & $\begin{array}{l}\text { 代らちふ } \\
\text { すB菊 }\end{array}$ \\
\hline 19 & 川 & 村 & 15 & 京 大 & 1280 & $10(-)$ & $10(-)$ & 63生 & 40 & $10(-)$ & $10(-)$ \\
\hline 20 & 中 & 村 & 15 & " & 1280 & 20 & 160 & "I & 40 & $10(-)$ & 40 \\
\hline 21 & 有 & 政 & 16 & 桃 山 & 20480 & 40 & 160 & "1 & 320 & $10(-)$ & 40 \\
\hline 22 & 高 & 浦 & 18 & 京 都 & 2560 & $10(-\cdots)$ & 160 & 鹽酸 & 160 & $10(-)$ & $10(-)$ \\
\hline 23 & 今 & 井 & 19 & 京 大 & 1280 & 10 & 160 & 63生 & 80 & $10(-)$ & 40 \\
\hline 24 & 寺 & 田 & 19 & 京 都 & 640 & $10(-)$ & 80 & " & $10(-)$ & $10(-)$ & 10 \\
\hline 25 & $\equiv$ & 好 & 20 & 桃山 & 5120 & 40 & 160 & 監酸 & 160 & $10(-)$ & 43 \\
\hline 26 & 五 & 味 & 20 & $\cdot 11$ & 1280 & 10 & 40 & " & 40 & $\mathrm{I} 0(-)$ & 10 \\
\hline 27 & 加 & 藤 & 20 & 京 都 & 20480 & $10(-)$ & 80 & " & 320 & $10(-)$ & 80 \\
\hline 28 & 中 & 井 & 21 & 京 大 & 160 & $10(-)$ & 80 & " & 20 & $10(-)$ & 20 \\
\hline 29 & 長 & 尾 & 21 & 京 都 & 2560 & 40 & 80 & 17 & 80 & $10(-)$ & 10 \\
\hline 30 & & & 21 & 京 大 & 2560 & $10(-)$ & 160 & "l & 80 & $10(-)$ & $\left.8^{\prime}\right)$ \\
\hline 31 & 藤 & 本 & 21 & & 1280 & $10(-)$ & $10(-)$ & "I & 80 & $10(-)$ & 10 \\
\hline
\end{tabular}

第 3 表二示ス如ク，本笁デ取扱ツタ血清ガ總デ腸ちふす患者ノ血清デアルコトハ明膫デア， 


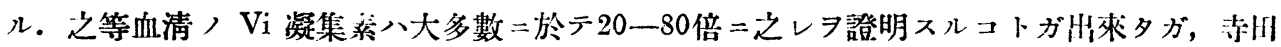

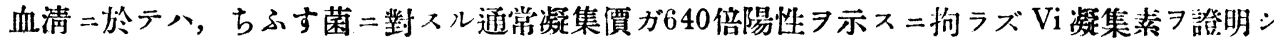
得ナカツタノデアル。文川村血清 (19) 八第 2 表 ( 9 及ビ12) =於テ示シタト同一患者カラ 探取シタモノデアルガ, 發病後15日＝至リ漸ク $\mathrm{Vi}$ 凝集素ノ出現习證明シ得タモノデアル。

以上第 $1 ， 2 ， 3$ 節

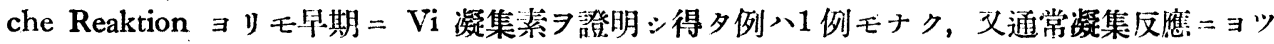
テちふす菌二對スル凝集素习證明シ得ルニ拘ラズ之レ二對スル Vi 凝集素 イ實驗例ノ存在スルコトハ注意スベキコトデアルト思フ。

第 4 第 發病第 4 週乃至 12 週二於ヶル血清二關スル成績

本䈯

\begin{tabular}{|c|c|c|c|c|c|}
\hline " & 5 & " & $29-35$ & "I & $10 /$ \\
\hline "I & 6 & "I & $36-42$ & "I & $5 \%$ \\
\hline "I & 7 & "I & $43-49$ & "I & $8 \%$ \\
\hline "I & 8 & "I & $50-56$ & II & $5 /$ \\
\hline " & 9 & "I & $57-63$ & $/ 1$ & $2 \%$ \\
\hline "I. & 11. & "I & $71-77$ & $1 /$ & 2 \\
\hline II & 12 & "I & $78-84$ & /I & $1 / 1$ \\
\hline II & 26 & II & $176-182$ & "I & 1 \\
\hline
\end{tabular}

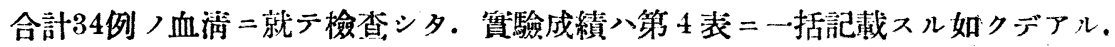

第 4 表。

\begin{tabular}{|c|c|c|c|c|c|c|c|c|c|c|c|}
\hline \multirow{2}{*}{$\begin{array}{l}\text { 探時 } \\
\text { 血期 } \\
\end{array}$} & \multirow{2}{*}{$\begin{array}{l}\text { 番 } \\
\text { 號 }\end{array}$} & \multirow{2}{*}{ 血 清 名 } & \multirow{2}{*}{$\begin{array}{l}\text { 發䈪昌 } \\
\text { 後數 }\end{array}$} & \multirow{2}{*}{$\begin{array}{l}\text { 血由 } \\
\text { 清 } \\
\text { 來 }\end{array}$} & \multicolumn{3}{|c|}{ 通 常 凝 集 反 應 } & \multirow{2}{*}{$\begin{array}{l}\text { Vi-血淸 } \\
\text { 調製法 }\end{array}$} & \multicolumn{3}{|c|}{ Vi - 凝 集 反䜿 } \\
\hline & & & & & ちふす葡 & $\mid \begin{array}{l}\text { さらちふ } \\
\text { すA菌 }\end{array}$ & $\begin{array}{l}\text { ばらちふ } \\
\text { すB菌 }\end{array}$ & & ち心す菌 & $\mid \begin{array}{l}\text { はちちふ } \\
\text { す月菌 }\end{array}$ & $\begin{array}{l}\text { ばらち子 } \\
\text { すB菌 }\end{array}$ \\
\hline \multirow{2}{*}{ 第 } & 32 & 田 & 22 & 桃山 & 1280 & 43 & 160 & 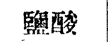 & 43 & $10(-)$ & 10 \\
\hline & 33 & 谷 & 25 & 京都 & 1280 & 10 & 80 & 11 & 40 & $10(-)$ & 80 \\
\hline \multirow[t]{2}{*}{4} & 34 & 梶 & 27 & 京大 & 1280 & $10(-)$ & 40 & 63生 & 40 & $10(-)$ & $10(-)$ \\
\hline & 35 & 黑 & 28 & 京都 & 640 & 10 & 40 & "I & 20 & $10(-)$ & $4: 3$ \\
\hline 週 & 36 & 坂 & 28 & "I & 20480 & 10 & 40 & 臨酸 & 163 & $10(-)$ & 20 \\
\hline \multirow{5}{*}{ 第 } & 37 & 濱 & 29 & 京大 & 1283 & $10(-)$ & 80 & 嚂酸 & 80 & $10(-)$ & 10 \\
\hline & 38 & 坂 田 & 29 & 京都 & $256 J$ & 10 & 320 & "I & 2) & $10(-)$ & 40 \\
\hline & 36 & 中 & 30 & 京大 & 320 & $10(-)$ & $10(-)$ & "1 & 23 & $10(--)$ & $10(-)$ \\
\hline & 40 & 坂 & 30 & 桃山 & 1280 & 40 & 320 & "I & 8) & $10(-)$ & 83 \\
\hline & 41 & . 金 & 31 & "I & 10240 & $4 J$ & 320 & 63生 & 160 & $10(-)$ & 40 \\
\hline 5 & 42 & 杉 原 & 31 & 京都 & 326 & $10(-)$ & $10(-)$ & 監酸 & 20 & 2) & 10 \\
\hline
\end{tabular}




\begin{tabular}{|c|c|c|c|c|c|c|c|c|c|c|c|c|}
\hline \multirow{2}{*}{$\begin{array}{l}\text { 探時 } \\
\text { 血期 } \\
\end{array}$} & \multirow{2}{*}{$\begin{array}{l}\text { 番 } \\
\text { 號 }\end{array}$} & \multirow{2}{*}{\multicolumn{2}{|c|}{ 血 渡 名 }} & \multirow{2}{*}{$\begin{array}{l}\text { 登， } \\
\text { 病旦 } \\
\text { 挠數 }\end{array}$} & \multirow{2}{*}{$\begin{array}{l}\text { 血由 } \\
\text { 清 } \\
\text { / 來 }\end{array}$} & \multicolumn{3}{|c|}{ 通 常 凝 集 反應 } & \multirow{2}{*}{$\begin{array}{l}\text { Vi-血清 } \\
\text { 調製法 }\end{array}$} & \multicolumn{3}{|c|}{ Vi-凝 集 反准 } \\
\hline & & & & & & 万系す菌 & 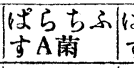 & 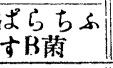 & & ちふす菌 & 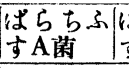 & $\begin{array}{l}\text { は⿱⺊口丂 } \\
\text { すB菌 }\end{array}$ \\
\hline \multirow{4}{*}{ 週 } & 43 & 杉 & & 32 & 京暗 & 640 & $10(-)$ & 80 & 監酸 & 20 & $10(-)$ & 40 \\
\hline & 44 & 武 & 市 & 33 & 桃山 & 1280 & $10(-)$ & 320 & $" \prime$ & 80 & $10(-)$ & 80 \\
\hline & 45 & 辻 & & 34 & "I & 2560 & 20 & 40 & 63生 & 80 & $10(-)$ & 40 \\
\hline & 46 & 笠 & 井 & 34 & 京都 & 320 & $10(-)$ & 40 & "I & 20 & $10(-)$ & 20 \\
\hline \multirow{2}{*}{ 第 } & 47 & 足 & 立 & 36 & 京部 & 2560 & 10 & 320 & 臨酸 & 80 & $10(-)$ & 40 \\
\hline & 48 & 小 & 森 & 38 & 挑山 & 5120 & 40 & 320 & ." & 160 & $10(-)$ & 20 \\
\hline \multirow[t]{2}{*}{6} & 49 & 橋 & 本 & 38 & 京都 & 1283 & 10 & 160 & $"$ & 40 & $10(-)$ & 40 \\
\hline & 50 & 渡 & 湟 & 39 & 桃山 & 2560 & 10 & 160 & "I & 83 & $10(-)$ & 20 \\
\hline 週 & $5 i$ & 松 & 田 & 41 & 京都 & 1280 & 10 & $8)$ & "I & 40 & $10(-)$ & 80 \\
\hline 第 & 52 & 足 & 立. & 45 & 京都 & 5120 & 40 & 40 & 63生 & 160 & $10(-)$ & 20 \\
\hline 7 & 53 & 佐 々 & 木 & 47 & 桃山 & 640 & 10 & 160 & " & 40 & $10(-)$ & 40 \\
\hline 週 & 54 & 立 & 入 & 48 & 京都 & 1280 & 10 & 160 & 監酸 & 20 & $10(-)$ & $10(-)$ \\
\hline \multirow{2}{*}{ 第 } & 55 & 尾 & 崎 & 51 & 桃山 & 2560 & 40 & 160 & 監酸 & 80 & $10(-)$ & $10(-)$ \\
\hline & 56 & 大 & 澤 & 52 & 京都 & 640 & 10 & 320 & " & 20 & $10(-)$ & 10 \\
\hline \multirow[t]{2}{*}{8} & 57 & 加 & 䇣 & 53 & 桃山 & 2560 & 40 & 80 & 63生 & 80 & $10(-)$ & 40 \\
\hline & 58 & 木 & 村 & 55 & 11 & 1280 & $10(-)$ & 160 & "I & 80 & $1.0(-)$ & 10 \\
\hline 週 & 59 & 本 & 澤 & 56 & 京都 & 640 & 10 & 80 & 籃酸 & 20 & $10 \div-$ & 20 \\
\hline \multirow{2}{*}{$\begin{array}{c}\text { 第 } \\
9 \\
\text { 週 } \\
\end{array}$} & 60 & 矢 & 野 & 59 & 桃山 & 320 & $10(-)$ & 160 & 63生 & 40 & $10(-)$ & 80 \\
\hline & 61 & 山 & 田 & 59 & "I & 640 & 83 & 80 & " & 40 & $10<-$ & 20 \\
\hline \multirow{2}{*}{$\begin{array}{l}\text { 第 } \\
11 \\
\text { 週 }\end{array}$} & 62 & 今 & 川 & 76 & 挑山 & 640 & 80 & 80 & 63生 & 40 & $10(-)$ & 20 \\
\hline & 63 & 長 & 棟 & 77 & 京都 & 1280 & 10 & 40 & "I & 40 & $10(-;$ & 40 \\
\hline 第12週 & 64 & 中 & 田 & 84 & 京大 & 1280 & 20 & 40 & 63生 & 40 & 20 & 40 \\
\hline 第26週 & 65 & 䄸 & 田 & 177 & 京都 & 640 & 10 & 80 & 63生 & 40 & $10(-)$ & 40 \\
\hline
\end{tabular}

第 4 表ニ示ス如ク，本實驗=供試シタ34例／血清八總テちふす患者ノモノデアルコト 八明 ラカデアリ, 又之等二於テハ總テちふす菌ニ對スル Vi 凝集素习證明スルコトガ出來タノデ

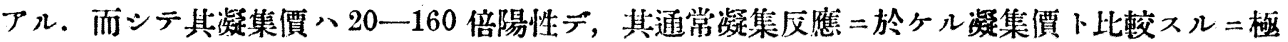
メ低度デアル.

\section{第 5 第 既往ニ於テちふすフ經驗セル健康者血清二關スル成䋶}

腸ちふす雉患恢癒後 1 年乃至 20 年經過シタ健康者血清 7 例（總テ敎室關係者ヨリ探取） 7 供試シタ. 苗驗成績八第 5 表 $=$ 示ス.

第 5 表二示ス如ク，66，67，70，71，72 各血清ノちふす菌=對スル通常凝集反應二於ヶ 几凝集價八低度デ，之等八正常凝集價ノ範圍シ越へナイモノデアルガ，68，69 >兩血清 $=$ 於 


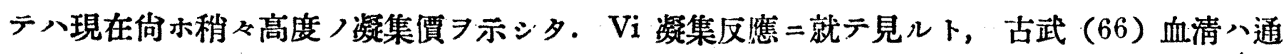
常凝集反應つ凝集價、100倍以下ナル 拘ラズ，ちふす菌 $=$ 對スル Vi 凝集素八 1 年後 $=$ 於テ モ可成り高度＝證明サレルノデアッテ、コノ腸ちふす八再發习苍起シ極メテ重篤ナル經過 取ツタモノテアル，又通常凝集反應二於テ稍々高イ凝集價 ヨ示シタ濱田 (68) 並二藤井 (69) ノ兩血清及ビ他ノ血清＝於テハ Vi 凝集素ヨ全ク證明シ得ナカツタノデアル.

第 5 表

\begin{tabular}{|c|c|c|c|c|c|c|c|c|c|c|}
\hline \multirow{2}{*}{$\begin{array}{l}\text { 番 } \\
\text { 號 }\end{array}$} & \multirow{2}{*}{\multicolumn{2}{|c|}{ 血 清名 }} & \multirow{2}{*}{$\begin{array}{l}\text { 經年 } \\
\text { 過數 }\end{array}$} & \multirow{2}{*}{\multicolumn{3}{|c|}{ 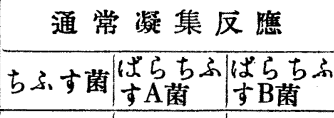 }} & \multirow{2}{*}{$\begin{array}{l}\text { Vi血清 } \\
\text { 調製法 }\end{array}$} & \multicolumn{3}{|c|}{ Vi－凝集 反飪 } \\
\hline & & & & & & & & ち心す菌 & 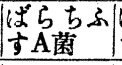 & 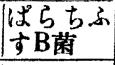 \\
\hline 66 & 古 & 武 & 1 年 & 80 & $10(-)$ & 80 & 63生 & 160 & $10(-)$ & $10(-)$ \\
\hline 97 & 綸 & 田 & 15年 & 40 & 10 & 160 & " & $10 i-2$ & $10(-)$ & 40 \\
\hline 68 & 濱 & 田 & "I & 160 & $10(-)$ & 40 & " & $10(-)$ & $10(-)$ & 20 \\
\hline 69 & 滕 & 井 & " & 320 & $10(-)$ & 160 & " & $10(-)$ & $10(-)$ & 40 \\
\hline 70 & 靑 & 地 & 17年 & 10 & $10(-)$ & 10 & " & $10(-)$ & $10(-)$ & 10 \\
\hline 71 & 河 & 原 & " & 40 & $10(-)$ & 10 & "I & $10(-)$ & $10(-)$ & 20 \\
\hline 72 & 西 & 田 & 20 年 & 20 & $10(-)$ & 20 & " & $10(-)$ & $10(-)$ & 10 \\
\hline
\end{tabular}

本䡠驗 成績カラスレバ，ちふす菌二對スル Vi 凝集素八恢復後 1 年迄八證明シ得ルカ， 通常凝集素=比ベテ概シテ早期＝消失スルモノデアルコトハ明ラカデアルト思フ.

\section{第 3 章 總括考按並二結論}

本編 =於テハ，余等ガ京阪地方デ蒐集シタちふす患者並 = 同恢復者血清及ビ兓往=於テ腸 ちふす 7 經驗シタ者ノ血清總計72例二就テ，ちふす菌二對スル Vi 凝集少 7 檢索シテ得夕成 績

發病後第 1 及ビ 2 週 =探取シタ血清 18 例 =關スル成績 他 ’血清ニアツテハ, 通常凝集反應二於テ160 万至 2560 倍 凝集價 7 得夕. 從テ之等ガ總テ 腸ちふす患者血清デアル事ハ明カデアリ，又通常凝集反應二於ヶルト同一血清二就テ之ト併 行シデ貫施シタ Vi 凝集反雇二於テハ, 6 例 $(4,5,6,9,10,17)$ ヨ除ク他諸例二於テ 夫ょ10乃至80倍ノ陽性成績ヨ得タノデアル。然シ乍ラ, 茲二选ダ興味アル成績ハ渡逶及ビ川 村血清=關スルモ?デァツテ, 發病第 7 日目二探取シ夕渡邊血清 $(4)=$ 於テハ未ダちふす 菌 $=$ 對ス几通常並 $=\mathrm{Vi}$ 兩凝集素ノ出現 7 證明シ得ナイガ, 同一患者ヨリ14日後二探取シタ 血清=於テハ, 其ノちふす菌=對スル通常凝集價八640倍陽性デアルノ=Vi凝集素八前回= 於ヶルト同樣二全ク之ヨ證明スル事ガ出來ナカツタモノデアル. 又川村血清二於テ八發病第 10日目二探取シタ血清八通常凝集反應=於テちふす菌＝對シテ320倍，凝集價 ヨ示シタガ Vi 凝集素ハ全ク之习證明スル事ガ出來ナイデ, 其つ第 12 日目二探取シタ血清八通常凝集反應二 
於デちふす菌＝對シ1280倍陽性デアツテ，Vi 凝集素八渐ク10倍陽性ヨ示シタ事デアル. 從

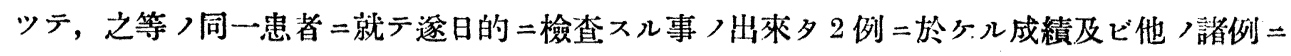
於ヶル成績カラシテ，Vi 凝集素ノ出現八通常凝集素ノ其レニ比べテ時間的=逮延スルモ， デアリ，又 Vi 凝集價八通常凝集反烣二於ケル凝集價=比ベテ甚ダ低度ノモノデアル事八明 㫿ナ事實デアル。

腸ちふすノ診斷二屡く應用サレル Widalsche Reaktion 八墢病第 1 週ノ終リカラ第 2 週二

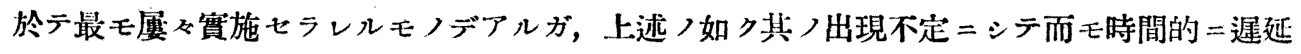
スル Vi 凝集素ノ出現习證明スル事 二向ツテハ全ク價值ナキモノデアルト云ハネバナラナイ。

發病後第 3 週二於テ探取シタ13例ノ血清二關スル成績=就テ觀ル二, 之等八通常凝集反應 つ成績カラ腸ちふす患者血清デアル事八明白デアルガ, 其, Vi 凝集反應二於テハ, 發病第 19日目二探取シタ寺田（24）血清 ヨ除ク他ノ供試血清デハちふす菌=對スル Vi 凝集素 20 倍陽性以上:=於テ證明スル事が出來, 而モ 2 例〔有好 (21) 及ビ加藤 (27)〕 =於テ八全實 驗例 通ジテ最高 Vi 凝集價タル320倍陽性（コノ場合通常凝集價八网者共20480倍陽性デア ル） ヨ示シタノテアル。從テ Vi 凝集價八發病第 3 週二於テ略其ノ最高期=達スルモノト推

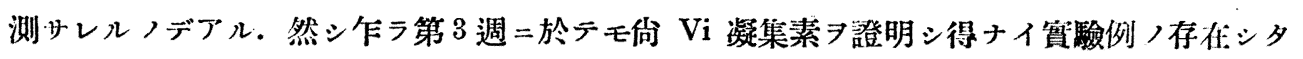

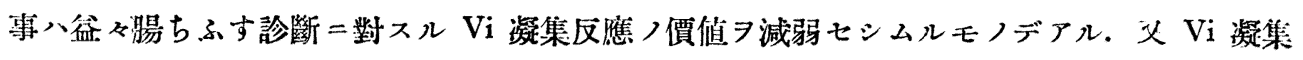
價八, 前期=於ヶルト同樣，通常凝集反應二於ヶル其レヨリモ甚ダ低度ノモノデアル。

發病第 4 週乃至 26 週=至儿間 =探取シタ供試血清 34 例 =關スル成績 =於テハ, 通常並 $=\mathrm{Vi}$ 凝集反應 㒳者 $=$ 於テ陽性成績 $コ$ 得儿事ガ出來タガ, 此ノ場合 $=$ 於テモ亦 Vi 凝集賈八通常 凝集反應=於ヶル凝集價=比べテ極メテ低度ノモノデアル。

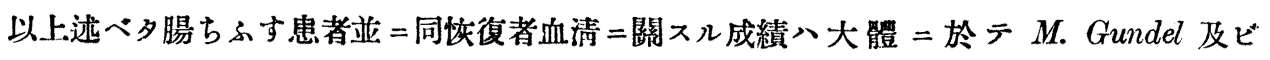
Y. B. Abdoosh(3), Felix. A, Krikorian. K. S. 及ビ Seitler. R. (2), Horgen. E. S.(4)等， 所見ト一致スル所デアル.

既往ニ於テ腸ちふすフ經驗シタ者ノ血清 7 例中古武血清ニ於テノミ Vi 凝集素习證明スル 事ガ出來夕・本例八毁二述ベタ如ク，1年前二極メテ重症ナル腸ちふすフ經驗シタモノデア ツテ, 其〉經過カラスレバー特殊例卜看做スベキモノデアリ, 本血清=於テハ通常凝集反應 ニ於ヶルョリモ稍々高度 $=\mathrm{Vi}$ 凝集素习證明スル事ガ出來タノデアル. 其ノ他ノ6 例中羅患 後15年 $ᄏ$ 經過シタ 2 例 $(68,69)$ ノ血清=於テハ稍ぬ高度ノ通常凝集價ヨ示シタガ, 之等= 於テハ總テちらす菌＝對スル Vi 凝集素习證明スル事ハ出來ナカツタノデアル。

倘余等八, 腸ちふす患者血清, Vi 凝集價卜當該疾病つ豫後卜ノ關係二就テ考察 
ノデアルガ, 本實驗＝記載シタ患者二於テハ，コノ問題＝關シデー貫シタ成績 來ナカツタモノデアル.

\section{結 敦}

1. 腸ちふす患者並二同恢復者血清及ビ既往二於テ腸ちふすヨ經驗シタ者ノ血清總計72例 二就テ, ちふす菌二對スル Vi 凝集素习檢索シタ.

2. 發病第 1,2 及ビ 3 週 =探取シタ患者血清=於ヶル Vi 凝集素ノ出現ハ不定デアツテ, 而モ其ノ出現八通常凝集素ノ出現=比べラ時間的二稍々僬延スル.

從ツテ Vi 凝集反應八腸ちふす，早期診斷ノ目的二向ツテハ全ク價值ナキモノデアル.

3. 發病第 4 週以後第 26 週＝至ル間二探取シタ血清ニ於テハ八每常 Vi 凝集㨞习證明シ得夕.

4. 全賽驗例 通ジテ Vi 凝集價八通常凝集反隹ニ於ヶル凝集價ニ比べテ甚ダ低度ノモ， デァツタ.

5. 既往ニ於テ腸ちふすフ經驗シタ者ノ血清ニ就テハ, 極メテ重症且特異ナ經 過

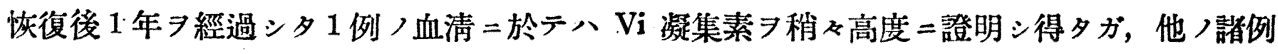
二於テハ之习證明スル事八出來ナカツタ.

6. 腸ちふす患者血清, Vi 凝集價卜疾病ノ魥後卜ノ間=ハ一貫シ夕關係ハナイモノノ如 クデアル.

擱筆 $=$ 臨ミ恩師木村呚授 つ御指導並 $=$ 御校閱 $=$ 對シテ深謝ス. 又患者血清 澤京都病院長及ビ熊谷大阪桃山病院長=謝意习表スル。

\section{.文献}

1) 田部井, 梅敷, 遠藤, 片网 : 日微生物誌, 第32卷 302 頁, 昭和 13 年.

2) Folix, A.,

Krikorian, K. S. 及ビ Seitler, R. : J. of Hyg., Vol. 35, P. 421, 1935.

M. Gundel 及ビ Y. B. Abdoosh : Zbl. Bakter., I Orig, Bd. 136, S. 54, 1936.

4) Horgen, E. S. : J. of Hyg. Vol. 36, P. 368, 1936 